\title{
Meningkatkan prestasi belajar ilmu pengetahuan alam melalui pendekatan lingkungan pada siswa sekolah dasar
}

\author{
Inti Sukawati \\ SD Muhammadiyah Branjang. Branjang, Ngawis, Kec. Karangmojo, Kabupaten Gunung Kidul, Daerah Istimewa Yogyakarta 55891, Indonesia \\ intisukawati@mail.com \\ * corresponding author
}

ARTICLE INFO

Keywords

Prestasi belajar

pendekatan lingkungan

Pembelajaran IPA

\begin{abstract}
Penelitian ini bertujuan untuk meningkatkan prestasi belajar Ilmu Pengetahuan Alam (IPA) melalui pendekatan lingkungan pada siswa kelas III SD Muhammadiyah Branjang Karangmojo Gunungkidul. Penelitian ini merupakan Penelitian Tindakan Kelas (PTK) dengan menggunakan analisis secara kuantitatif dan kualitatif. Metode pengumpulan data melalui observasi dan tes. Subjek penelitian adalah siswa kelas III yang berjumlah 12 siswa pada siswa kelas III SD Muhammadiyah Branjang Karangmojo Gunungkidul. Penelitian dilaksanakan dalam dua siklus dengan melibatkan teman sejawat sebagai observer. Siklus penelitian dilaksanakan sebanyak dua kali pada bulan Oktober 2016. Hasil penelitian menunjukkan bahwa: (1) pada siklus pertama ditemukan sebagian besar siswa memperoleh nilai di bawah Kriteria Ketuntasan Minimal (KKM), yaitu sebanyak $40 \%$. (2) pada siklus kedua didapatkan perolehan nilai siswa di atas Kriteria Ketuntasan Minimal (KKM) dari semula dari 40\% meningkat menjadi 100\% dari seluruh siswa. Berdasarkan hasil penelitian dapat disimpulkan bahwa melalui pendekatan lingkungan pemahaman siswa kelas III SD Muhammadiyah Branjang meningkat secara signifikan.
\end{abstract}

\section{PENDAHULUAN}

Pendidikan Ilmu Pengetahuan Alama (IPA) di sekolah dasar bertujuan agar siswa menguasai pengetahuan, fakta, konsep, prinsip, proses penemuan, serta memiliki sikap ilmiah, yang akan bermanfaat bagi siswa dalam mempelajari diri dan lingkungannya atau alam sekitar. Pendidikan IPA menekankan pada pemberian pengalaman langsung untuk mencari tahu dan berbuat sehingga mampu menjelajahi dan memahami alam sekitar secara ilmiah. Pengembangan pembelajaran IPA yang menarik, menyenangkan, sesuai konteks, serta didukung oleh ketersediaan waktu, keahlian, sarana dan prasarana merupakan kegiatan yang tidak mudah untuk dilaksanakan. Seorang guru dituntut memiliki kemampuan dan kreatifitas yang cukup agar pembelajaran dapat terselenggara secara aktif dan efisien. Namun kenyataannya pembelajaran IPA biasa diajarkan secara konvensional hampir di setiap sekolah dasar, dengan metode klasik ceramah sehingga menciptakan kejenuhan dalam belajar, karena terkesan hanya guru yang aktif dan siswa cenderung pasif hanya mendengarkan saja. Hal tersebut menyebabkan kurangnya pemahaman siswa terhadap materi ajar. Hal ini dapat dilihat dari hasil tes akhir pembelajaran mata pelajaran IPA pada materi penggolongan tumbuhan. Dari jumlah siswa kelas III sebanyak 14 siswa dengan KKM 72, hanya 4 siswa yang mampu mencapai KKM atau sekitar 33,3\% sedangkan 10 siswa atau 66,7 \% belum mencapai KKM. 
Melihat kenyataan tersebut peneliti tergugah untuk memperbaiki pembelajaran IPA melalui perbaikan pembelajaran, agar prestasi yang diharapkan dapat tercapai dengan baik. Melalui pendekatan lingkungan ini diharapkan kemampuan siswa dalam memahami materi penggolongan tumbuhan benar-benar mengalami kemajuan. Pendekatan menurut (Turville, 2008), adalah cara umum dalam memandang permasalahan atau objek kajian, sehingga berdampak ibarat seseorang memakai kacamata dengan warna tertentu pada saat memandang alam sekitar. (Susilo,1998:), mengemukakan bahwa pendekatan bersifat aksiomatis yang menyatakan pendirian, filosofi, dan keyakinan yang berkaitan dengan serangkaian asumsi.

Peranan pendekatan pembelajaran adalah menyesuaikan antara tujuan pembelajaran, siswa, latar belakang sosial budaya, sumber belajar dan daya dukung yang tercakup dalam unsur input, output, dan produk pendidikan dengan bahan kajian yang akan disajikan, sehingga pembelajaran menjadi menarik, menyenangkan, menimbulkan rasa ingin tahu, memberikan penghargaan serta bermakna bagi hidup dan kehidupan sekarang dan yang akan datang. Tujuan penggunaaan pendekatan adalah menggiring cara pandang/persepsi dan atau proses pengkajian terhadap materi pelajaran dengan suatu terminologi sehingga akan diperoleh suatu pemahaman dan pembentukan perilaku siswa yang diharapkan.

Prinsip pemilihan pendekatan adalah pertimbangan pendekatan yang dipilih dengan faktor-faktor terkaitnya, antara lain seperti tujuan pendidikan dan pembelajaran, kurikulum, kemampuan siswa, dan sumber daya. Berdasarkan Kurikulum 2004, tujuan pembelajaran IPA di Sekolah Dasar (SD) adalah agar siswa mampu: (a) mengembangkan pemahaman dan pengetahuan konsep IPA yang bermanfaat dan dapat diterapkan dalam kehidupan sehari-hari; (b) mengembangkan rasa ingin tahu, sikap positif, dan kesadaran adanya hubungan saling mempengaruhi antara IPA, lingkungan, teknologi dan masyarakat; (c) mengembangkan ketrampilan proses untuk menyelidiki alam sekitar, memecahkan masalah, dan membuat keputusan; (d) berperan serta dalam memelihara, menjaga, dan melestarikan lingkungan alam; (e) menghargai alam dan segala keteraturannya sebagai salah satu ciptaan Tuhan; (f) memiliki pengetahuan, konsep, dan ketrampilan IPA sebagai dasar untuk melanjutkan pendidikan jenjang berikutnya.

Peneliti memilih menggunakan pendekatan lingkungan karena disesuaikan dengan latar belakang, budaya, dan ekonomi peserta didik. Pendekatan lingkungan adalah mengajarkan IPA dengan cara pandang bahwa mengembangkan kebiasaan siswa menggunakan dan memperlakukan lingkungan secara bijaksana dengan memahami faktor politis, ekonoms, sosial budaya, ekologis, yang mempengaruhi manusia dalam memperlakukan lingkungan tersebut. Pada pendekatan ini, pembelajaran dikembangkan dengan menggunakan lingkungan sebagai sumber belajar, untuk mengembangkan sikap peduli dan mencintai lingkungan, dan untuk mengembangkan ketrampilan meneliti lingkungan

Dalam proses pembelajaran ada beberapa masalah yang menghambat keberhasilan siswa, antara lain: (1) Siswa belum bisa berkonsentrasi penuh terhadap pelajaran; (2) belum tepatnya pendekatan yang dilakukan oleh guru; (3) guru terlalu mendominasi pembelajaran; (4) siswa kurang aktif pada saat pembelajaran berlangsung; (5) hasil yang dicapai siswa belum maksimal terbukti sebagian besar nilainya dibawah KKM. Pembelajaran IPA di SD menekankan pada pemberian pengalaman belajar langsung melalui penggunaan dan pengembangan ketrampilan proses dan sikap ilmiah. Sebagai seorang guru, kita dituntut untuk dapat memilih pendekatan yang dapat memberi kesempatan dalam memberikan pengalaman belajar langsung melalui penggunaan dan pengembangan ketrampilan proses dan sikap ilmiah. Pemilihan pendekatan yang paling cocok harus disesuaikan dengan tujuan pembelajaran, materi yang akan disampaikan, sumber, situasi, dan kondisi lingkungan. Berikut adalah beberapa pendekatan yang digunakan dalam pembelajaran IPA.

Penelitian Tindakan Kelas (PTK) ini dilaksanakan pada bulan Oktober 2016 di SD Muhammadiyah Branjang Kecamatan Karangmojo Kabupaten Gunungkidul Daerah Istimewa Yogyakarta. Subyek Penelitian adalah dari siswa kelas III SD Muhammadiyah Branjang Tahun Pelajaran 2016/ 2017. Penelitian Tindakan Kelas ini dilaksanakan dalam dua siklus sampai tujuan penelitian tercapai yaitu meningkatkan prestasi belajar siswa. Pada Penelitian Tindakan Kelas ini peneliti menjadi instrumen utama dimana peneliti menjadi pengumpul data. Peneliti juga menjadi perencana dan pelaksana tindakan kelas yang terlibat langsung dengan siswa dalam proses penelitian.Instrumen pendukung lain yang digunakan untuk memperoleh data yaitu lembar observasi dan test tertulis.

Dalam pengumpulan data peneliti menggunakan beberapa cara yaitu: Pengamatan partisipatif, observasi aktifitas kelas, pengukuran hasil belajar, prestasi belajar. Prestasi belajar diartikan sebagai 
tingkat keterkaitan siswa dalam proses belajar mengajar sebagai hasil evaluasi yang dilakukan guru. Prakosa,menyatakan bahwa prestasi belajar adalah seberapa jauh hasil yang telah dicapai siswa dalam penguasaan tugas-tugas atau materi pelajaran yang diterima dalam jangka waktu tertentu yang pada umumnya dinyatakan dalam angka atau huruf sehingga dapat dibandingkan dengan satu kriteria." (Handarini, 2019; Lastriningsih, 2017).

Sejalan dengan pendapat itu Sunarya (1983:4), menyatakan bahwa prestasi belajar merupakan perubahan tingkah laku yang meliputi ranah kognitif, afektif, dan psikomotorik yang merupakan ukuran keberhasilan siswa (Sunarya, 1983:4, dalam belajar psikologi.com/pengertian-prestasibelajar. Diakses pada 4 Agustus 2016). Dengan demikian prestasi belajar merupakan kemampuan seseorang dalam pencapaian berpikir yang tinggi. Prestasi belajar harus memiliki tiga aspek, yaitu kognitif, afektif, dan psikomotor. Prestasi belajar dari siswa adalah hasil yang telah dicapai oleh siswa yang didapat dari proses pembelajaran. Dapat juga diartikan sebagai pencapaian maksimal menurut kemampuan anak pada waktu tertentu terhadap sesuatu yang dikerjakan, dipelajari, dipahami, dan diterapkan.

Menurut Piaget karakteristik anak SD mengibaratkan bahwa anak bukanlah seperti botol kosong yang siap untuk diisi, melainkan anak secara aktif membangun pengetahuan dunianya. Piaget juga mengajarkan kita pada suatu kenyataan bahwa seluruh anak mengikuti pola perkembangan yang sama tanpa mempertimbangkan kebudayaan dan kemampuan anak secara umum. Hanya umur anak dimana konversi muncul sering berbeda. Poin yang penting ini menjelaskan kita mengapa pembelajaran IPA di SD banyak menggunakan percobaan maupun lingkungan sebagai sumber belajar dan berhasil pada anak yang lemah dan secara kebudayaan terhalangi (Sapriati, 2009).

Berdasar teori Piaget tersebut dapat dikatakan bahwa pembelajaran harus mempertimbangkan keadaan tiap siswa (terpusat pada siswa) dan siswa diberikan banyak kesempatan untuk mendapatkan pengalaman dari penggunaan indranya. Dengan demikian, untuk meningkatkan prestasi siswa sebaiknya siswa diberikan kesempatan untuk mendapatkan pengalaman langsung yang mudah diingat serta siswa berpartisipasi aktif dalam pembelajaran sehingga guru tidak terkesan mendominasi kelas dan pembelajaran berlangsung menarik dan menyenangkan. Ilmu Pengetahuan Alam adalah suatu ilmu yang mempelajari tentang alam sekitar beserta isinya. Hal ini sesuai dengan pengertian: Ilmu Pengetahuan Alam adalah ilmu yang mempelajari gejala-gejala alam yang dapat dirumuskan kebenarannya secara empiris (intaniarizkyu0808.blogspot.com/definisi ilmu pengetahuan alam. Diakses pada 6 Agustus 2016).

Sehingga, untuk mempelajari ilmu ini, siswa selayaknya mempelajarinya secara langsung atau dengan kata lain siswa terjun langsung ke lapangan atau lingkungan sekitar pada saat melakukan proses belajar mengajar. Definisi tersebut didukung oleh pendapat Lumbung Pustaka UNY: Ilmu Pengetahuan Alam (IPA) atau science dapat disebut sebagai ilmu tentang alam. Ilmu yang mempelajari peristiwa-peristiwa yang terjadi di alam ini (eprints.uny.ac.id/BAB2/08108244136.pdf. diakses pada 6 Agustus 2016). Untuk memahami esensi materi pada IPA, sebaiknya siswa dihadapkan pada kejadian-kejadian alam yang dapat diamati secara langsung. Misalnya, siswa dibimbing untuk mengamati lingkungan di sekitar sekolah sebagai sumber belajar.

Hal ini sesuai dengan pendapat Trowbridge dan Bybee (1996), yang menyatakan: “... Ilmu Pengetahuan Alam merupakan representasi dari hubungan dinamis yang mencapai tiga faktor utama yaitu the extand body of scientific knowledge, the values of science, and the method and procecces of science, yang artinya sains merupakan produk dan proses serta mengandung nilai-nilai." Pembelajaran IPA sebaiknya dilakukan dengan metode atau pendekatan yang menarik untuk membangkitkan minat dan semangat siswa. Hal ini bertujuan untuk memotivasi siswa agar lebih aktif dalam mencari pembuktian tentang suatu materi pembelajaran yang pada akhirnya siswa bisa menemukan dan menyimpulkan sendiri suatu materi pembelajaran dengan bahasa yang mereka pahami.

Jadi, Ilmu Pengetahuan Alam merupakan ilmu yang mempelajari benda-benda alam dan kejadian alam yang diperoleh dari hasil percobaan dan pengamatan manusia, yang bertujuan agar siswa menguasai pengetahuan, fakta, konsep, prinsip, proses penemuan, serta memiliki sikap ilmiah, yang akan bermanfaat bagi siswa dalam mempelajari diri dan lingkungannya atau alam sekitar. Pendekatan lingkungan adalah mengajarkan IPA dengan cara pandang bahwa mengembangkan kebiasaan siswa menggunakan dan memperlakukan lingkungan secara bijaksana dengan memahami faktor politis, sosial budaya, ekologis yang mempengaruhi manusia dalam memperlakukan lingkingan tersebut. Pada pendekatan ini, pembelajaran dikembangkan dengan menggunakan lingkungan sebagai 
sumber belajar, untuk mengembangkan sikap dan perilaku peduli dan mencintai lingkungan, serta untuk mengembangkan ketrampilan meneliti lingkungan (Sapriati, 2009).

Pendekatan pembelajaran yang bermakna akan membantu konsep-konsep yang ditemukan siswa selama proses pembelajaran mempengaruhi daya retensinya. Belajar memerlukan keterlibatan aktif baik berupa manipulasi langsung, penginderaan, maupun mengeksplorasi atas inisiatif sendiri. Memfokuskan hal-hal yang menarik bagi anak jauh lebih baik dibanding menarik perhatian mereka untuk melakukan aktifitas atas pilihan guru. Teori yang sesuai dengan pendekatan lingkungan adalah teori belajar kognitif, (Mulyani, 2013), yang menyatakan bahwa dasar dari pengembangan pendekatan lingkungan adalah teori belajar kognitif yang memberi tekanan pada organisasi pengamatan atas stimulus di dalam lingkungan serta faktor-faktor yang mempengaruhi pengamatan (Widyasari et al., 2015).

Dari pandangan Piaget tentang tahap perkembangan kognitif anak dapat dipahami bahwa pada tahap tertentu cara maupun kemampuan anak mengkonstuksi ilmu berbeda-beda berdasarkan kemampuan intelektual anak. Piaget mengemukakan bahwa pengetahuan tidak diperoleh secara pasif oleh seseorang, melainkan melalui tindakan. Hal tersebut senada dengan pandangan (Corebima, 2006), yaitu: Pengajaran yang baik mengajarkan siswa bagaimana belajar, bagaimana mengingat, bagaimana berpikir, dan bagaimana memotivasi diri mereka sendiri. (simpangmahar.blogspot.com, diakses 7 Agustus 2016). Dengan demikian lingkungan merupakan salah satu sumber belajar yang amat penting dan memiliki nilai yang sangat berharga dalam rangka proses pembelajaran siswa. Penggunaan lingkungan memungkinkan terjadinya proses belajar yang lebih bermakna, sebab anak dihadapkan pada kondisi yang sebenarnya.

\section{METODE}

Data dalam penelitian ini merupakan data yang diperoleh dari observasi pembelajaran baik di dalam maupun di luar kelas. Pengumpulan data diambil dengan melakukan observasi terhadap aktivitas siswa dan guru, serta tes tertulis. Observasi dilaksanakan melalui dua siklus dengan pelaksanaan alur kegiatan yang sama. Materi yang dibahas dalam kedua siklus ini merupakan materi yang sama yang pada akhir masing-masing siklus dilaksanakan ters tertulsi untuk mengetahui tingkat pencapaian siswa. Tujuan dari pelaksanaan kedua siklus ini adalah untuk memperbaiki pembelajaran. Proses pengumpulan data dalam penelitian ini menggunakan beberapa instrumen yang meliputi RPP, lembar observasi aktivitas siswa dan guru selama proses pembelajran di dalam dan di luar kelas, dan format tes tertulis. Tujuan dari pelaksanaan tes adalah untuk mengetahui ketercapaian siswa selama proses pembelajaran.

Tekhnik pengumpulan data penelitian ini adalah: pertama dengan data kualitatif, pengujian terhadap hipotesis bahwa penggunaan pendekatan lingkungan dapat meningkatkan pemahaman siswa kelas III SD Muhammadiyah Branjang tersebut dinyatakan dalam bentuk kualitatif. Artinya terjadi peningkatan atau tidak terjadi peningkatan pemahaman konsep bagi siswa kelas III SD Muhammadiyah Branjang dengan pendekatan lingkungan. Kedua dengan data kuantitatif. Sebagai alat ukur keberhasilan penelitian digunakan tes tertulis. Tes tertulis yang digunakan dalam penelitian ini adalah tes tertulis yang berbentuk isian singkat dan uraian. tes tulis merupakan tes dalam bentuk tulisan yang digunakan untuk mengukur pengetahuan dan penguasaan materi mengenai materi tertentu. Hasil tes ini sangat bermanfaat untuk merencanakan tindakan selanjutnya yang harus dilakukan guru dalam proses belajar mengajar.

Setelah melaksanakan pembelajaran dengan pendekatan lingkungan siswa belajar langsung dengan menggunakan lingkungan sekolah sebagai sumber belajar, maka pada akhir kegiatan pembelajaran guru memberikan tes tertulis untuk mengukur kemampuan siswa. Melalui tes ini, guru akan menganalisis berapa persen siswa yang mampu menguasai materi dengan baik. Jika sebagian besar siswa atau seluruh siswa memperoleh nilai sesuai KKM atau melebihi KKM maka siswa tersebut dinyatakan berhasil dalam mengikuti kegiatan belajar mengajar. Namun, jika sebagian besar siswa mendapatkan nilai di bawah KKM, maka guru harus merencanakan tindakan selanjutnya untuk dapat meningkatkan prestasi siswa. 


\section{HASIL DAN PEMBAHASAN}

\section{Pra Siklus}

Pada kegiatan pembelajaran pra siklus, siswa memperoleh nilai yang kurang memuaskan yaitu sebagian siswa memperoleh nilai di bawah KKM. Nilai tersebut dapat ditunjukkan pada Tabel 1 .

Table 1. Nilai siswa kelas III pra siklus

\begin{tabular}{cccc}
\hline No. & Nama Siswa & Nilai & Keterangan \\
\hline 1. & Alya Fina N & 65 & Belum tuntas \\
2. & Abdussalam A & 50 & Belum tuntas \\
3. & Asyifa & 60 & Belum tuntas \\
4. & Feby W & 60 & Belum tuntas \\
5. & Jenny Sisca A & 65 & Belum tuntas \\
6. & Ririk P & 60 & Belum tuntas \\
7. & Vonny C & 85 & Tuntas \\
8. & Yumna S & 75 & Tuntas \\
9. & Abhgi W & 65 & Belum tuntas \\
10. & Bagus W & 85 & Tuntas \\
11. & Ahmad H & 60 & Belum tuntas \\
12. & Akbar D & 65 & Belum tuntas \\
\hline
\end{tabular}

\section{Siklus I}

Pada siklus pertama ini diperoleh hasil bahwa pemahaman materi penggolongan tumbuhan berdasar bentuk daun masih rendah karena jumlah siswa yang memperoleh nilai di bawah KKM lebih dari $50 \%$. Pada tahap siklus I ini para siswa masih kesulitan dalam memahami materi penggolongan tumbuhan berdasar bentuk daun meski peneliti sudah menampilkan berbagai gambar daun. Padahal peneliti melihat bahwa para siswa sebenarnya bisa lebih paham akan materi dengan media gambar berbagai bentuk daun karena metode tersebut memiliki kelebihan. Ketidakberhasilan pada Siklus I karena siswa belum bisa membayangkan penggolongan tumbuhan berdasar bentuk daun itu seperti apa. Akibatnya para siswa kesulitan menjawab pertanyaan tentang penggolongan tumbuhan. Para siswa masih rancu dalam memahami materi. Hal ini karena peneliti masih kurang dalam mengupayakan pendekatan yang tepat agar siswa memahami materi penggolongan tumbuhan berdasar bentuk daun. Peneliti hanya menunjang pembelajaran dengan berbagai gambar/ foto berbagai tumbuhan dan bentuk daun.Dalam pembelajaran jumlah siswa yang nilainya di atas KKM ada 4 siswa atau sekitar $33 \%$ dari total jumlah siswa.

Table 2. Daftar nilai IPA materi penggolongan tumbuhan

\begin{tabular}{ccccccccc}
\hline \multirow{2}{*}{ No. } & Nama siswa & \multicolumn{9}{c}{ Jawaban } & \multirow{2}{*}{ Nilai } & Keterangan \\
\cline { 3 - 6 } & & No. 1 & No. 2 & No. 3 & No. 4 & No. 5 & & \\
\hline 1. & Alya Fina N & 20 & 10 & 15 & 10 & 10 & 65 & Belum tuntas \\
2. & Abdussalam A & 15 & 10 & 15 & 10 & 10 & 60 & Belum tuntas \\
3. & Asyifa & 20 & 10 & 15 & 10 & 10 & 65 & Belum tuntas \\
4. & Feby W & 20 & 10 & 15 & 10 & 10 & 65 & Belum tuntas \\
5. & Jenny Sisca A & 20 & 10 & 10 & 15 & 10 & 65 & Belum tuntas \\
6. & Ririk P & 20 & 10 & 15 & 10 & 5 & 60 & Belum tuntas \\
7. & Vonny C & 20 & 15 & 20 & 10 & 20 & 85 & Tuntas \\
8. & Yumna S & 20 & 10 & 20 & 10 & 15 & 75 & Tuntas \\
9. & Abhgi W & 20 & 10 & 15 & 10 & 10 & 65 & Belum tuntas \\
10. & Bagus W & 20 & 10 & 20 & 10 & 15 & 75 & Tuntas \\
11. & Ahmad H & 20 & 10 & 15 & 5 & 10 & 60 & Belum tuntas \\
12. & Akbar D & 20 & 15 & 20 & 10 & 20 & 85 & Tuntas \\
\hline
\end{tabular}

Melihat kurang efektifnya penggunaan gambar dalam pembelajaran serta kriteria indikator keberhasilan yang ditentukan adalah $77 \%$ atau 8 siswa nilainya di atas KKM maka peneliti berdiskusi dengan supervisor untuk melakukan penelitian pada tahap siklus II. Nilai yang diperoleh siswa dalam siklus II dapat dilihat pada Tabel 2. 


\section{Siklus II}

Pada Siklus II penelitian perbaikan menggunakan pendekatan lingkungan yang telah dilakukan menunjukkan peningkatan yang signifikan. Pada Siklus II ini 100\% siswa dari 12 siswa telah mencapai nilai KKM dalam pemahaman penggolongan tumbuhan yang pertanyaannya sama dengan teks pada Buku Siswa. Adapun teks dan soal atau pertanyaan yang digunakan pada penelitian siklus II dapat dilihat dalam Lampiran 2. Peningkatan pemahaman penggolongan tumbuhan ini karena para siswa melihat langsung berbagai macam tumbuhan yang ada di lingkungan sekolah sehingga para siswa tidak hanya menebak jenis-jenis tumbuhan dan bentuk tulang daunnya. Keberhasilan pencapaian target kriteria indikator pada siklus II ini dengan rincian jumlah siswa yang nilainya di atas KKM ada 12 siswa atau 100\% dari total jumlah siswa. Target ketercapaian perbaikan yang ditetapkan peneliti adalah $90 \%$ siswa dapat mencapai Kriteria Ketuntasan Minimal (KKM). Hasil pencapaian tersebut dapat dilihat pada Tabel 3 .

Table 3. Daftar nilai IPA materi penggolongan tumbuhan berdasarkan bentuk daun

\begin{tabular}{|c|c|c|c|c|c|c|c|c|}
\hline \multirow{2}{*}{ No. } & \multirow{2}{*}{ Nama siswa } & \multicolumn{5}{|c|}{ Jawaban } & \multirow{2}{*}{ Nilai } & \multirow{2}{*}{ Keterangan } \\
\hline & & No. 1 & No. 2 & No. 3 & No. 4 & No. 5 & & \\
\hline 1. & Alya Fina N & 15 & 10 & 20 & 15 & 10 & 70 & Tuntas \\
\hline 2. & Abdussalam A & 15 & 10 & 20 & 15 & 20 & 80 & Tuntas \\
\hline 3. & Asyifa & 20 & 10 & 15 & 15 & 15 & 75 & Tuntas \\
\hline 4. & Feby W & 20 & 10 & 15 & 15 & 15 & 75 & Tuntas \\
\hline 5. & Jenny Sisca A & 20 & 20 & 20 & 15 & 15 & 90 & Tuntas \\
\hline 6. & Ririk P & 20 & 15 & 15 & 15 & 15 & 80 & Tuntas \\
\hline 7. & Vonny C & 20 & 20 & 20 & 15 & 15 & 90 & Tuntas \\
\hline 8. & Yumna S & 20 & 10 & 20 & 15 & 15 & 80 & Tuntas \\
\hline 9. & Abhgi W & 20 & 15 & 15 & 15 & 20 & 80 & Tuntas \\
\hline 10. & Bagus W & 20 & 20 & 20 & 20 & 20 & 85 & Tuntas \\
\hline 11. & Ahmad H & 20 & 15 & 15 & 15 & 15 & 80 & Tuntas \\
\hline 12. & Akbar D & 20 & 20 & 20 & 15 & 25 & 90 & Tuntas \\
\hline
\end{tabular}

Table 4. Daftar Nilai IPA materi penggolongan tumbuhan berdasar bentuk daun pada pra siklus, siklus I, dan siklus II

\begin{tabular}{|c|c|c|c|c|c|}
\hline No. & Nama & Pra siklus & Siklus I & Siklus II & Ket \\
\hline 1. & $\mathrm{AF}$ & 65 & 65 & 75 & \\
\hline 2. & AA & 50 & 60 & 80 & \\
\hline 3. & AFP & 60 & 65 & 75 & \\
\hline 4. & FW & 60 & 65 & 75 & \\
\hline 5. & JSA & 65 & 65 & 90 & \\
\hline 6. & $\mathrm{RP}$ & 60 & 60 & 80 & Tuntas \\
\hline 7. & VCS & 85 & 85 & 90 & \\
\hline 8. & YSK & 75 & 75 & 80 & \\
\hline 9. & AW & 65 & 65 & 80 & \\
\hline 10. & BW & 65 & 75 & 85 & \\
\hline 11. & $\mathrm{AH}$ & 60 & 60 & 80 & \\
\hline 12. & $\mathrm{AD}$ & 85 & 85 & 90 & \\
\hline
\end{tabular}

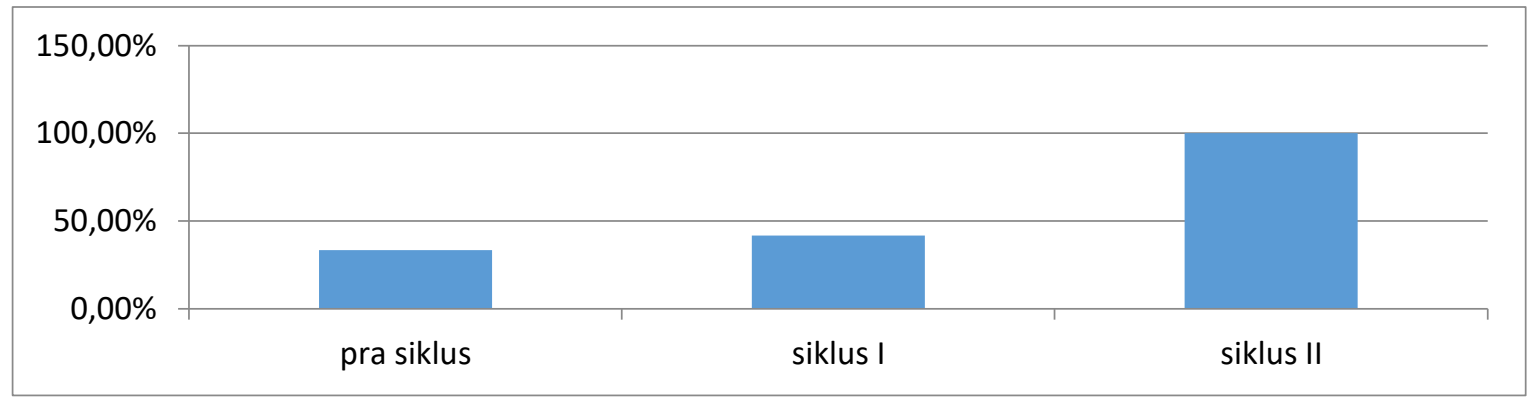

Gambar 1. Nilai IPA materi penggolongan tumbuhan berdasar bentuk daun pada pra siklus, siklus I, dan siklus II 


\section{SIMPULAN}

Berdasarkan hasil perbaikan pembelajaran yang telah dilaksanakan dalam dua siklus dapat disimpulkan bahwa ada peningkatan pemahaman penggolongan tumbuhan pada siswa kelas III melalui pendekatan lingkungan. Hal ini ditunjukkan dengan adanya peningkatan beberapa aspek yaitu: (1) Nilai rata- rata kelas III dalam materi penggolongan tumbuhan menunjukkan peningkatan di setiap siklusnya; (2) Peningkatan jumlah siswa yang mendapat nilai sesuai atau diatas KKM yang ditetapkan yaitu 70. Pada kegiatan belajar pra siklus, jumlah siswa yang memperoleh nilai di atas 70 sebanyak 33,3\%. Pada kegiatan penelitian Siklus I, hasil perolehan nilai para siswa lebih baik meski yang nilainya $70 \mathrm{ke}$ atas sebanyak $44,6 \%$ tetapi siswa yang lain juga mengalami peningkatan nilai. Pada kegiatan penelitian Siklus II, terjadi peningkatan pemahaman penggolongan tumbuhan melalui pendekatan lingkungan. Seluruh siswa mencapai nilai sesuai atau diatas KKM.

\section{REFERENSI}

Corebima, A. D. (2006). Metakognisi: Suatu ringkasan kajian. In Pelatihan Strategi Metakognitif pada pembelajaran biologi untuk guru-guru biologi SMA.

Handarini, D. M. (2019). Kontribusi faktor-faktor non-kognitif pada prestasi belajar siswa sekolah menengah pertama. Psychology, Evaluation, and Technology in Educational Research, 1(2). https://doi.org/10.33292/petier.v1i2.22

Lastriningsih, L. (2017). Peningkatan berpikir kritis dan prestasi belajar melalui metode inquiry pada siswa kelas IV SD. Jurnal Prima Edukasia, 5(1), 68-78. https://doi.org/10.21831/jpe.v5i1.7714

Mulyani, D. (2013). Hubungan kesiapan belajar siswa dengan prestasi belajar. Konselor, 2(1). https://doi.org/10.24036/0201321729-0-00

Sapriati, A. (2009). Pembelajaran IPA di SD. Universitas Terbuka.

Trowbridge, L. W., \& Bybee, R. W. (1996). Teaching secondary school science: Strategies for developing scientific literacy. Simon \& Schuster Books For Young Readers.

Turville, J. (2008). Differentiating by student learning preferences. Routledge. https://doi.org/10.4324/9781315854694

Widyasari, A., Sukarmin, S., \& Sarwanto, S. (2015). Pengembangan modul fisika kontekstual pada materi usaha, energi, dan daya untuk peserta didik kelas X SMK Harapan Kartasura. Inkuiri, $4(2), 125-134-134$. 